Journal of Family Diversity in Education

Volume 3 Number 32019

http://familydiversityeducation.org/index.php/fdec

\title{
"We have stories to share!": Narratives of Identity and Perspectives of Japanese Descent Teachers in the USA
}

\author{
Gumiko Monobe \\ Kent State University, USA \\ Barbara L. Seidl \\ University of Colorado, Denver, USA
}

\begin{abstract}
As the number of immigrant children entering school systems increases across the globe, preparing teachers to support these children and their families is of critical importance. How to support and bring strength to English language learners (ELLs) and immigrant children is a new subject among the scholarship of teacher education, due to the increasing numbers of immigrant children. There are unique complexities that educators need to consider, including: (a) their own cross/bicultural, bilingual identity development, (b) their interpersonal relationship building, and (c) their hybrid experiences in a culturally and linguistically unfamiliar environment with other children and teachers in a new country.

In this study, we focus mainly on three teachers who are of Japanese descent and their support of Japanese immigrant students. Findings from this study suggest that the three teachers used their funds of knowledge (González, Moll, \& Amanti, 2005) as immigrants and immigrant teachers to support their Japanese immigrant students in the following three categories: building interpersonal connections, cross-cultural mediation, and nurturing identity development in the context of hybridity and wholeness.
\end{abstract}

Keywords: immigrant children, English language learners, immigrant teachers, bi/multilingual teachers, narrative inquiry 
Monobe and Seidl

\section{Conceptual Framework}

Narrative inquiry through a feminist lens can help shed the light on the fact that the many voices and perspectives of people who have been historically and politically ignored and silenced present missed opportunities for recognizing valuable knowledge and theory. This marginalization and silencing has been historically controlled by mainstream and politically powerful populations such as upper-middle-class whites. This is true in the field of education, too. Because the voices of female immigrant teachers of color, and particularly for this paper, female Japanese immigrant teachers, have been absent in education and teacher education in the United States, their perspectives are important contributions to this research.

Therefore, we chose narrative inquiry as our conceptual framework, combining narrative and feminist theories in order to better understand the way stories and storytelling construct meaning and theorize collaboratively, especially for underrepresented populations. Narrative theory helps us focus on how people make sense of their identities; in particular, cultural contexts through narrative (Bruner, 1987, 1996; Kanno, 2003). Bruner (1986, 1996) discusses the relationship between narrative and culture in the continuous process of identity construction and explores how people make sense of themselves in particular cultural contexts through narrative.

Making sense of one's self through narrative involves high cognitive activities that include interpretation, reflection, and theorization of events, and involves an examination of life events within/without their cultural context (Dillard, 2006). Therefore, we made a conscious effort to create time, space, and opportunities for the participants and the researcher to co-create missing knowledge and theories through talking, listening, reflecting, and re-interpreting together. Narrative inquiry is a useful method in achieving these processes. It is our belief that theorization of one's own experiences and life are a crucial benefit of narrative inquiry, especially for groups of people whose voices and knowledge have not been recognized or valued as knowledge and theory that can contribute to society (Dillard, 2006). All of the participants' stories, which explore the funds of knowledge that come from their experiences and knowledge as bilingual, bicultural, transnational, racial/biracial people, were valued. It is inevitable and important that we gather stories about the intersections of their life experiences beyond who they are as teachers.

\section{Methodology}

This paper is a small portion of a larger narrative case study of three immigrant teachers of Japanese descent. The study explores the voices and experiences of these teachers in their work with immigrant children who were primarily Japanese first-generation immigrant children and considers how the narratives of the teachers' life experiences and identities, especially being cross/bicultural and cross/bilingual, helped shaped a culturally responsive pedagogy. The research question for this particular paper is: How do these three Japanese immigrant teachers use their lives and experiences to identify important priorities that support their ELL/immigrant children? And how did they create such supportive strategies for their ELL/immigrant children? 
"We have stories to share!"

\section{Definition of Terms}

There are several different generations of immigrants, such as the first, 1.5, and second generations. The term first generation refers to people who are born in a different country and move as adults to a new country to live. Therefore, in this study, this definition refers to the parents and caregivers of ELL and immigrant children. The term 1.5 generation refers to people who are born in a different country but move to a new country while they are still children or early teenagers. The term second generation refers to the people who are children of the first generation of immigrants and who are born in the new country (Zhou, 1997a, 1997b). In this paper, we refer to immigrant children who are mostly 1.5- and second-generation immigrants. Zhou (1997a, 1997b) emphasizes the different sets of experiences and relationships between the home and host country among first, 1.5, and second generations of immigrants. For instance, the immigrant population is a transitional generation, and many first-generation immigrant adults who live with 1.5- and second-generation immigrant children do not necessarily have similar cross/bicultural and bilingual experiences and expectations in their everyday lives in the host country.

Additionally, in this article, we define terms as follow:

Asian. Asians and Asian immigrants are linguistically, historically, culturally, economically, and religiously highly diverse, therefore it is important to be aware of and respect these differences. At the same time, there are some important similarities among Asian immigrants. For instance, in Asian immigrant family school relationships and literacy learning: Patterns and explanations, Li and Sun (2019) argue that

[d] espite the cultural variance within the pan-Asian community, Asian immigrant parents at the same time share many similar struggles within the educational disparities between the Asian and Western words (30).

In this paper, we use the term "Asian" not to diminish the differences. The term was especially used when the participants of this study use the term.

Bicultural/multicultural. Individuals or groups who obtain some degree of knowledge of the culture, social rules, and communication patterns of two or more cultures in order to live in more than one culture or society.

Hybridity/hybrid. The condition of having two or more cultural, social, linguistic, religious and/or national backgrounds, and her/his identities are constructed by two or more of these elements, which can change depending on the contexts.

Immigrant and immigrant children/youth. Regardless of their parents or caregivers' legal status, we use the term "immigrant children" to describe all children for whom one or both parents and caregivers has or have moved from another country and all children who have moved from another country. We also use the term regardless of their parent(s)/caregivers intention to stay in the United States permanently or not. In this paper, English Language Learners (ELL), English as a Second Language (ESL) students, and immigrant are used interchangeably when the particular child is identified as an ESL student or needs English 
language support in her/his school. The first author used the term participants used during narrative data collection.

Ibasho (居場所). Ibasho is "a place and community to belong" in Japanese. We use the term Ibasho as a metaphorical term to describe a space where people can feel safe and comfortable, as well as experience a sense of belonging and acceptance of who they are. In Ibasho, people can engage and practice membership in the community by experiencing a sense of agency in their interactions with each other.

Third Space. Not defined by one culture and/or one language characteristics, third space is where people can experience and exchange their multiple cultures, languages, or religion, for example. Third space is characterized by participants' ability to move among multiple cultures and languages.

Transnational. Referring to immigrants who maintain social, economic, and cultural contact with both the sending and receiving countries (Wong, 2007). We also used the term transnational to refer to the lifestyle that immigrant people create within the United States in order to maintain and preserve their original cultural and social contexts of both the sending and receiving countries.

\section{Setting and Participants}

The settings for this study were all middle-class to upper-middle-class, primarily Caucasian public schools in multiple cities within 90 miles of the capital city of a Midwestern state in the United States. The three teachers in this study have lived and taught in both Japanese and US cultural contexts in Japan and the United States, and they are bilingual in Japanese and English.

In order to collect the depth and nuance of participants' voices as cross/bicultural and bilingual teachers, teacher participants had to meet the following criteria:

- Be first-, 1.5-, or second-generation Japanese immigrant teachers who speak both English and Japanese and who have lived, learned, and taught in both Japanese and US cultural/social contexts;

- Exhibit a strong commitment to working with immigrant children, especially Japanese children;

- Be easily accessible (Yin, 2014).

The experiences and qualifications of the three teachers are in the next section. Kei is a former student of the first author in the M.Ed. in early childhood (K-3) licensure program. The second participant is Kei's mother, Maki (pseudonyms). Maki's initial licensure is a firstthrough sixth-grade teacher license from Japan. Gumiko, the first author of this study, has taught both children and adults.

This research was conducted at areas which are close to one capital town, George (anonymous) in the Midwest USA. There is a major university at George: the same university from which Kei and Gumiko graduated. Maki lived a town an hour drive from George. Since this 
study focused on the participants' life and teaching experiences in/between/beyond Japanese and US cultural and linguistic contexts, we include brief but complete information about their learning and teaching history for readers.

Maki (真紀). Maki is a first-generation immigrant from Hiroshima, Japan. She married a white, American soldier when she was 19 years old. They moved to Hawaii and after that, lived in Japan and the United States from time to time. She and her husband went back to Hiroshima, so that Maki could finish her undergraduate degree in education. While she was getting her degree, she was teaching English for local children in Hiroshima.

By the time we did this research, Maki had taught for sixteen years as a full-time teacher at a public high school in "a smaller size, middle-class town" in the US. Her teaching position was to teach content areas for English as a second language (ESL) students. She said that she went to students' classrooms sometimes but mostly students came to her classroom to get support for content areas from their lessons in their mainstream classrooms. Maki shared that this position was created to address the increasing amount of needs of the ESL students, especially the increasing numbers of Japanese immigrants, and was made specifically for her. When this study was conducted, Maki was only working for one particular high school. But because of the number of ESL students, Maki was informed that she would also teach in middle school. Maki had about thirty students total for the year we gathered her stories. Maki said that $70 \%$ of her students were Japanese, mostly from middle-class backgrounds and the balance of her students were from India, Mexico, Puerto Rico, Philippines, China, and Myanmar. For 15 years, Maki also taught at a Japanese Saturday school in a larger town, approximately a twenty-minute drive from her home. She said that she was a sixth grade teacher for a long time.

Kei (恵). Kei is a second-generation immigrant who is biracial, having a Caucasian American father and Japanese mother. Maki is Kei's mother. Kei is fluently bilingual in both Japanese and English. Kei has been living transnationally between Japan and the United States all of her life. She was born in the United States and lived in Hiroshima, Japan between the ages of 4 to 6 . She attended an international preschool in Japan. She moved to the United States as a first grader. She attended school (grades 1-12) in a small university town in the middle eastern US. Kei, her younger sister, and her mom lived in Japan about 3 months every year during the summer until she was 20 years old. Kei also attended a Japanese Saturday School every Saturday from $1^{\text {st }}$ to $9^{\text {th }}$ grade. When she was an undergraduate student, she studied at a Japanese university for one year.

Kei has taught both Japanese and English in linguistic and cultural contexts. In this study, her past and current teaching experiences were both relevant. Kei was a classroom teacher in an international preschool for a year in Tokyo when she was studying at a university in Japan. Kei earned her Master of Education degree in Early Childhood at a major university in George. During her master's program, she was tutoring some Japanese immigrant students using both English and Japanese for multiple subjects, including Japanese and English language arts. During the time of this study, she taught at the first and second- grade levels. She was teaching ESL classes in two public elementary schools in George. Both schools were positioned between the 
city of George and the surrounding suburban area. There were increasing numbers of immigrant students including Japanese, South Korea and Latino/a. During this study, Kei also obtained her Teaching English as a Second Language (TESOL) endorsement.

Gumiko (ぐみ子). This is the first author of this study. Gumiko was born in Japan and immigrated to the US when she was 34 years old. Gumiko went to two undergraduate Education Programs in Japan and obtained $1-6^{\text {th }}$ grade and Pre-K teaching license in Japan. She had been a preschool/kindergarten teacher for eight years in Japan before moving to the United States to pursue her master's degree and eventually a Ph.D. in education. At the time of this study, she had lived in the United States for seven years and was teaching in several different settings, including four years of sixth-grade teaching at a Japanese Saturday School and approximately four years teaching Japanese immigrant children (K-12) as a tutor. Gumiko also worked as a university supervisor for student teachers for four years and as an instructor for undergraduate courses for two years at an Early Childhood Program at the university in George. Gumiko was Kei's supervisor when she was a student-teacher at the university.

Japanese Saturday school. This school is also called 補習校, Hoshuko, Japanese Supplemental Saturday schools, or Japanese heritage school (K-12). There was one Hoshuko in George and one close to where Maki lived. Kei attended a Hoshuko between first and ninth grade. Both Maki and Gumiko taught as $6^{\text {th }}$ grade classroom teachers in different Hoshukos. In addition, most of Maki, Kei, and Gumiko's students of Japanese descent attended Hoshukos every Saturday during the Japanese Academic year.

Hoshuko is a supplemental school for Japanese children and children of Japanese descent outside of Japan. The Hoshuko served students whose parents were working for a short time in the US (while the children were five to eight years) and would will eventually return to Japan; Japanese-American children whose families wanted them to acquire a sense of Japanese culture and a degree of fluency in the language, and bi-racial children with one Japanese or JapaneseAmerican parent. Hoshukos are located all over the world, including the United States. Since the school's agenda is not teaching Japanese language but to re-create Japanese society and community as a teaching and learning environment, I chose to use the term Hoshuko throughout this study.

The role of Hoshuko varied depending on the regions and students' needs. For example, the Hoshuko Gumiko taught at had about five hundred students due to a Japanese industry farm located close to the town of George. About seventy to eighty percent of students' parents were expected to go back to Japan. Therefore, the main educational goal of this Hoshuko was to prepare students for their return to Japan. Many Hoshuko use Japanese national standards, curricula, and textbooks used in public schools in Japan. When a school reaches a certain enrollment, the Japanese Ministry of Education and Science and Technology also sends a principal and vice-principal to that Hoshuko, which are located in various countries all over the world. They help to create transnational educational spaces for children of Japanese descent in different countries. Hoshukos, no matter where they are located, are embedded in the cultural, social, linguistic, historical, economic and political realities, and agendas of the places in which 
"We have stories to share!"

they are located. Usually, students learn Japanese language arts, mathematics, readings, and sometimes social studies or/and science.

\section{Data Collection and Analysis}

Narrative inquiry. Narrative inquiry provided both conceptual framework and methodological direction for the study. It allowed the exploration of the ways in which these teachers drew from the stories of their own lives and experiences to interpret their students' needs and create bi/multicultural and bi/multilinguistic responsive supports and teachings for them. Narrative inquiry proceeds from the belief that people lead "storied lives" in that, "people shape their daily lives by stories of who they and others are and...they interpret their past in terms of their stories" (Connelly \& Clandinin, 2006, p. 477). Narrative inquiry is particularly useful in examining the close relationship between personal voices and culture (Bruner, 1987, 1996) and how they are situated in multiple cultural contexts, societies, languages, families, other peoples, the past, and the future (Clandinin, Pushor, \& Orr, 2007).

Since the production of narrative is collaborative in nature and meaning is co-constructed by people listening and talking together, interactions between the participants and the researchers were conducted on equal terms with shared responsibilities. This approach also allowed the primary researcher to be positioned as a participant with two other participants, Maki and Kei. Within cooperative inquiry (Heron \& Reason, 1997), "all those involved in the research are both co-researchers and participants whose thinking and decision making contribute to generating ideas, designing and managing the project, [and] drawing conclusions from the data that were collected" (Reason, 1994, p. 326). Thus, at the beginning of the year-long study, the first author and the other two participants agreed that they would collect, discuss, and collectively interpret stories of their experiences in working with immigrant children. The two participant teachers chose Japanese pseudonyms by themselves 一真紀 (Maki) and 恵 (Kei). The first author negotiated what Connelly and Clandinin (1990) called the multiple "I's" of the researcher, moving from the researcher-I to "a teacher, woman, commentator, research participant, narrative critic, and theory builder" (p. 9).

Narrative data collection through story telling sessions (STS). All stories were collected across a 12-month period by the first author. All three participants-Kei, Maki, and Gumiko (the first author) — identify themselves as fluent English and Japanese speakers and writers. Therefore, both Japanese and English languages were used based on each participant's preferences without disturbing the narrative data collection process. For instance, Kei said that it was natural for her to speak in English when she spoke about anything relevant to teaching and learning theoretically since she gained the knowledge though her graduate program at a major university in the mid-eastern United States. For the first author, Gumiko, she spoke in Japanese when she talked about songs since that was where she learned songs as a child. Narrative and additional data included, but was not limited to, individual and group interviews, participants' writing, the researchers' journal, artifacts, and pictures. Some of the written documents were 
from the past and some were written during this research. All were shared by participants to provide clarity about their stories and for use in this study.

The primary sources of narrative data were through storytelling sessions (STS) that focused on the collection of stories from all three participants' personal histories as well as stories from their own teachings. Seven semi-formal individual sessions were held for both Maki and Kei. Each session was planned for one hour each, although some lasted much longer. Locations were selected based on Maki and Kei's preference and convenience. For instance, Maki lived about an hour and a half from the area where Kei and Gumiko lived. Gumiko drove to Maki's place when they had story telling sessions. Kei chose multiple locations, such as her apartment, her favorite Japanese tea shop, and her classrooms, which showed her intention to share her life with the first author.

Although the research was "semi-structured," the researcher allow participants to explore the topics freely. Often, after each session, Maki invited Gumiko to stay for Japanese tea, and they cooked and had lunch together. During the individual sessions, Gumiko's stories were also gathered simultaneously alongside Maki and Kei's conversations. Gumiko's stories were documented through her field notes, researchers' journal, and initial and developing analysis memo. In addition, Gumiko had informal conversations between each session by phone, face-toface, and through emails with Kei and Maki, seeking clarification or to point out additional thoughts. There were also three recorded group sessions, which lasted over two hours each including lunch, cooking, and/or tea time. The first author chose locations and contexts where participants could feel comfortable, connected, and go between/beyond Japanese, "American," and any other cultural, linguistic, and social boarders freely. For example, one of the sessions was at Gumiko's home where she cooked lunch for everyone. While entering Gumiko's house, Kei exclaimed, in Japanese with excitement and a big smile on her face，「日本人の人のうち の㫐いがする！」“It smells like a Japanese person's house!” The smell and food were part of our collective cultural memories.

Multiple sessions scheduled over the year allowed the participant-researcher to probe for details and interpretations and to follow up on links between stories of personal experience and stories of teaching. This is when the three group sessions were conducted. Group sessions were conversational and focused on obtaining stories about the participants' experiences as crosscultural and linguistic teachers within a culturally responsive, experiential framework. In both the individual and group sessions, the participant-researcher shared stories of her own in a dialogic format. All these sessions were audio-recorded and transcribed. All other more unofficial conversations, such as gathering to celebrate Thanksgiving, phone conversations, and email exchanges, were recorded immediately in the researcher's field notebook. Other data sources collected over time include: participants' writings, artifacts, former student writings, lesson plans, letters, pictures, communication from families, and photos. The first author kept a researcher's journal that was used to record field notes, develop analytical themes, and compose personal reflections on her status as a participant and researcher. 
"We have stories to share!"

Narrative data analysis. As we described previously, we used narrative inquiry for both narrative data collection (narrative collection) and the analysis. In narrative inquiry, data collection and data analysis are conducted simultaneously, which enhances the richness of both accumulating narrative data and data analysis while systematically supporting each other (SavinBaden \& Niekerk, 2007).

The narratives were analyzed and interpreted by retelling the stories in order to collectively think through commonalities and differences and explore big ideas as they were identified (Savin-Baden \& Niekerk, 2007). Narrative data analysis was inductive and emergent in that rather than applying a particular interpretive framework from the onset, concepts and themes were explored. As the stories were told and retold (Ellis, 2004), commonalities and connections across stories (Patton, 2002) were coded to arrive at meaningful themes. Themes were then analyzed to identify important characteristics.

All the writings, which included translation of Japanese STSs into English, were shared with the participants to ensure that their stories were portrayed accurately and to gain their perspectives on the interpretation of the stories for theorizing and member checking. Pseudonyms are used for the participant teachers and any children represented within the findings in this study.

The circulation of narrative data collection and data analysis process are as follows: narrative data collection; re-listening and re-reading the narrative data; writing a researcher's journal for interpretation, analysis, and reflection; creation of analytic codes, categories, and retelling stories as a process of analysis; writing analytic memos in the margins of transcripts; possible theory development data; planning for next narrative data session. Ongoing initial narrative data analysis focusing on emerging themes and possible theories helped the first author navigate the narrative data collection.

\section{Findings and Discussion}

Overall, the findings of this study indicate that the teaching of these three teachers proceeded from the set of experiences they had as immigrants and as people who were themselves living across multiple social, cultural, linguistic, racial, and national borders. Stories of their teaching, and the decisions they made were drawn from the rich tapestry of their own interpretation, reflection, and analysis of cross-cultural, social, linguistic, national, and education borders in their lives. They used these experiences to interpret the needs of their students and to construct culturally and linguistically relevant pedagogy that contain the following three important components that will be discussed in this report.

\section{Building Interpersonal Connections}

All three teachers in the study expressed that creating social connections/networks around each student is one of their most crucial duties because many of their students were at risk of becoming isolated in their school context. Isolation stemmed from a variety of reasons such as cultural, language, and social value differences and conflicts between students' home 
background culture and US “dominant” and/or school culture. Using Bronfenbrenner's ecological systems theory, Monobe \& Bedrosian (2018) claim that when parent(s) and teachers are from different ecological systems (i.e., macrosystems), and do not possess the communication competencies to effectively share information, the child(ren) may be left isolated at the intersection of two ecological systems. These authors advocate that immigrant/bilingual students need skillful adults to create a bridge between the cultural and linguistic systems and understand hybridity in between/beyond. The teacher participants in this study expressed similar concerns for many of their students who don't have Ibasho in their local US schools and who were in "mere survival mode." These three teachers worked with each student in flexible ways to make connections between peers, classroom teachers, and sometimes their family members.

Student to student. The three teachers emphasized having friends is a top priority for their students. Gumiko explained to Maki in story-telling sessions about the importance of making friends at local public school using one of her $6^{\text {th }}$ grade students in the hoshuko:

One of my students. Kyoko, ( $6^{\text {th }}$ grade, Hoshuko) wrote once in her free writing for my class, 'friends is like air. We cannot live without it.' It was about one month after Kyoko moved to USA from Japan. Kyoko is such a great student. She is really sweet, kind to anyone, and positive. She tried the best for everything. Many students of my class already like her and she started to make good friends. But she was having difficult time not to be able to make friends and find Ibasho in her local (public) school...."

Maki's pedagogy represented her understanding that this could not be forced, and she recounted her own experiences, as follows:

When I was a newer teacher I used to tell my students, 'You need to talk to American students.' Or 'Go and ask them to let you eat lunch with them.' I was pushing my students to take an initiative to make friends in school. But, I learned later that there were some students who could not really do it. For example, if I did not eat lunch with them, they were going to eat lunch alone. I started to be more flexible or softer depending on the student.

She takes on friend's role. Maki also explained about one female Japanese student she had when she was explaining her flexible strategies to support different students. Maki stated that sometimes, it can be easier for some Japanese ESL students to develop friendships with students from other countries rather than from their own. Maki said that since the population of the Japanese community is very small, there are students who do not get along well with the other children in their particular community. It is not rare for this to happen. With this knowledge, she asked some students from India to talk to the Japanese girl on their way back home one day. Maki explained that the student was lonely and did not have any friends yet. She said: 
"We have stories to share!"

How can I put it...they (the students from India) are simply very kind and good kids. So I told them about Satoko saying, "Satoko refused to come to school. If you go to her house to ask her to come to school together, I think she will come to school.' These students said, 'Really? Does Satoko feel lonely?' 'She wants to be friends with us?' They are really good and kind students so they could understand Satoko's loneliness.... It worked very well. They helped Satoko start to come to school again. After the talk, these students started to go to visit Satoko's house on the way to school to pick her up and they became good friends.

Maki recognized that the closeness within groups of people from the same ethnic background in very small communities could make things even more complicated in peer relationships. This instance demonstrates how Maki and other teachers work with individual students closely and adapt their approach depending on the particular situation of their students in local schools.

Students to classroom/content area teachers. Interpersonal relations among students and teachers in classrooms and schools have a great impact on the quality of education for each student (Gay 2000; Howard, 2001). Although it would be ideal for all classroom teachers to be able to have personal conversations with ELLs about things such as their families, friends, and interests, this is not likely to happen (e.g., Byrnes, Kiger, \& Manning, 1997; English, 2009; Reeves, 2006). For instance, Kei recounted how the principal in her school, who admitted that she did not know anything about ESL students' educations, told Kei that she and the other ESL classroom teacher could make all the decisions regarding their ESL students. Kei also stated that although the school had a relatively high number of ELL/immigrant students, the other classroom teachers are so busy that they seldom come to talk to her about the ELL students they share.

It is very important to create a space where ELL students can talk about their life and personal matters such as their families, friends, and interests with someone. Therefore, as a new teacher, Kei created a space in her ELL-only classroom where students can talk about personal stories with her and other classmates. For example, one of her students asked if she knew about a Muslim holiday called Eid ul-Fitr, but had not asked her classroom teacher. Children can feel what adults around them are thinking about them even if they don't say anything, which is why just having this kind of conversation is very important.

Kei understands the importance of dialogue with students in order to build mutual trustful relationships, which is a core of caring with culturally/linguistically reflective teaching (Gay, 2000, 2002; Howard, 2001; Witherell \& Noddings, 1991). In Telling Their Side of Stories: African-American Students' Perceptions of Culturally Relevant Teaching, Howard (2001) claims these actions by teachers should not just be words or feelings of caring but actions based on love, which are recognized by students (Howard, 2001). As an experienced teacher, Maki also used her knowledge about teachers in her school to consider which students will be a good match with which teachers. Maki told us, "If new immigrant/ELL students go to a classroom with a teacher 
who won't care and accommodate for the student, it will be a disaster for her/him." She continued:

When you choose classroom teachers for ESL students, it is important to choose someone who is willing to support their students in any kind of situation and issue, like I do. If the ESL teacher just sees his/her role as teaching English, it will be a very unfortunate and painful situation for his/her students.

Maki steps into the process of deciding which teacher's class she assigns her ESL students to, especially when the students are facing difficulties in the school. Because of ESL students' isolated situation in the school community, it is important to make sure that these students are sent to supportive environments. This kind of decision is crucial in supporting students who are at a potential risk academically, socially, or emotionally in school. Maki has built trustful relationships with some teachers who are passionate about supporting ESL students. When Maki notices that a student is having difficulties, she takes the initiative to communicate with other teachers to create a better and more caring environment for ESL students.

Building mutual connection with family members. All three teachers talked about their students' parents, and that they believe the parents feel comfortable making contact when there are questions or issues related to their children or their schools, due to their trusting relationship with each other (Gay, 2002; Howard 2001). Other commonalities between the three teachers were:

1. They make connections with students' parent(s) and family members outside of school contexts such as their homes, parents'/caregivers' work, and students' social events such as music/art/sports events or family events;

2. They truly enjoy communicating with students' parents/family members; and

3. They love to learn from students' family members about their lives, backgrounds, etc.

Maki shared stories about driving her students back to their homes after school many times (before her school had a stricter policy). She said that she drove many ESL students, from countries such as India, Vietnam, and China, back to their houses, in some cases, every day. She explained that sometimes her students stayed longer at school to study or do other activities, but since some of their parents did not have a driver's license yet, the children could not find rides home. Knowing that they were left alone in the school building, she could not leave them. She explained that these home visits became great opportunities for students' families and her to get to know each other and build trusting relationships. While she was talking about these experiences, she said many times with a smile, "The students' family members and students looked really happy when I visited their home." These visits helped her to understand what kind of family life her students had and what kinds of neighborhoods they lived in. She said:

One time, when I drove one of my students back to her house, something interesting happened. Many Indian people lived close to each other. When I went to the 
"We have stories to share!"

neighborhood, one of my students found me and said, "Oh! Maki! Do you want to come to visit my house?" so I said, "Sure!" And when I went to her house, there was an older sister lying in a living room. She was disabled so that she lay there most of the day. I thought that I now understood my student and her family life better. I talked with her parents. They were very happy to have me there. They had never had the experience of a teacher coming to visit their home since teachers usually don't do that in the United States. So, I decided to visit many of my students' homes.

She continued:

I visited many of my students' houses.... My students and their families gave me a variety of things when I visited their places. I thought 本当にアジアの人って、のりが 日本人と同じだよな [which means: Maki found many similarities between people from other Asian backgrounds and people from Japan regarding how to communicate, interact, show joy and appreciation. It provided a sense of familiarity and a comfortable feeling]. For example, when my students' family had me in their house, they had a tendency to want to give me something like Japanese people. One day, when I drove a student from China to his house, his grandpa was there. He said to me, "Here! Come and sit!" "Drink this!", "Eat this!", and gave me several things to try. When I visited other Chinese students, their families were very happy, too.

She explained how her visits helped her to understand her students from different perspectives and to build a more open and trusting relationship with them as well as with their family members. Maki uses her knowledge and experience as a frame of reference. But she also is able to expand her knowledge about her students and their families by willingly learning from them through prolonged communication in their family/cultural contexts. Theses teachers' actions are focused on making relationships with parent(s) extending beyond just "school matters." They are based on caring in the construction of mutual human relationships with parent(s)/caregiver(s)/family members (Chen, 2017; Gay, 2002; Howard 2001; Witherell \& Noddings, 1991).

\section{Developing Tools for Navigating Between Multiple Cultural Spaces}

Many scholars have discussed how the cultural mismatch between the home culture of students with a minority background and their school culture can be obstacles for students' social and academic success in schooling (e.g., Au \& Jordan, 1981; Gay, 2000; González, Moll, \& Amanti, 2005; Ladson-Billings, 1994; Phillips, 1983; Ogbu, 1987). Gay (2000) states, "Culture is the rule-governing system that defines forms, functions, and content of communication" ( $\mathrm{p}$. 79). Such a definition likens culture to the vocabulary and grammar in a language. The three teachers in the study recognize that just like people need to learn basic vocabulary and grammar in order to master new languages, students, parents, and teachers from different cultural backgrounds need to learn the cultural/social vocabulary and grammar of the new culture in 
order to communicate successfully (Mori, 1997; Yamada, 1997; Yoshino, 2004). The greater the differences between the social and cultural values of the home culture and school culture, the harder it is for students and their family members to feel accepted in the school community.

One of the most significant problems immigrant children face is that they, as well as their family members, do not know the social and cultural rules of their new cultural environment, which may be very different from, or even in conflict with, what they have been taught. The cultural rules are represented on what Maki calls a Cultural Coordinate Grid (CCG). CCG is useful for making meaning out of experience and guiding appropriate choices of behavior when one knows what defines the different $\mathrm{x}$ and $\mathrm{y}$ axes, such as good, bad, acceptable, unacceptable, and so forth. However, when these cultural coordinates are not known, it is impossible to determine where different behaviors, experiences, or interactions fall on the CCG or know how to adjust one's behavior to the new cultural environment. This is also true for the classroom and content area teachers' point of view.

The teachers in this study perceive that some students may have experienced these new cultural conflicts and can begin to feel rejected, or to reject the new culture and people within it, as a means of protection. The stories of these teachers emphasize the importance they place on the role of teachers acting as cultural mediators in order to help children and parents learn about the new cultural context and help them find their locations on the CCG. In doing so, they do not promote or reject assimilation into any culture. Their aim is to make visible the often invisible ways of thinking and acting within different contexts in ways that resist stereotypes and build respect for cultural diversity. Each of the teachers had experienced difficult or confusing experiences in new cultural contexts, just like the students and families they support.

Maki explained the feeling of being lost that many immigrant people experience. Using the CCG as a metaphor, she imagined the grid as a visual representation of the visible and hidden social and cultural rules that influence and guide behavior. Maki stated:

When you live in a foreign country, it is difficult to see where you are located on the grid. When something happens, you don't know where the incident should be located. Does it happen to everyone? Or does it happen more often to someone like me from another country? I had a strong fear of not being able to see the grid here in the US.

Kei experienced a similar sense of helplessness and powerlessness as a child of a mother from Japan. Although she was fluent in both English and Japanese from a young age, and her father is from the USA, her mother's lack of knowledge about US school culture prevented her from knowing what is normal in a US classroom. The cultural differences were very challenging for her, as she illustrates:

My mother did not always know...the norms of American life. When I entered the public school system in the United States, it was a learning experience for her as well. My mother's Japanese culture influenced my everyday life in American culture. Feeling 
"We have stories to share!"

ignorant about cultural norms made me feel different because I felt as though everyone else knew what to do but me.

Although Kei grew up with a Caucasian father and a Japanese mother, primarily in the United States, she had experiences that were very similar to those many immigrant students may experience. Kei expressed several times she did not know what was expected in the classroom when she started to attend an elementary school in the United States because she could not learn "what was natural and expected" from her parents (Gay, 2000). Despite her parents' rich experiences, Kei's quote still explains the complexity of the different experiences and needs that adults and children in immigrant populations face (Zhou, 1997a, 1997b). Since the adult populations of immigrants do not necessarily have experience living as children in the United States, they may not know what kind of cultural experiences and knowledge are lacking from their children's daily lives in comparison to their peers in school (Zhou, 1997a, 1997b). For instance, most students of Maki, Kei and Gumiko did not have any adult role models at home who grew up and/or taught in/between two or more language and cultural contexts. Maki, Kei and Gumiko are keenly aware of this challenging situation for their students. Therefore, they used their experiences to help not only their students but also parents/caregivers and teachers/administrators to understand what may cause cross-cultural miscommunication and misunderstanding. The three teachers also use their own challenging stories to help teachers understand ELL/immigrant students' communication challenges better.

"Active or passive." Particular characteristics of cultural differences contribute to immigrant children having different experiences as well. What is considered a "good citizen" in different cultures will influence actions and communication of people from those cultures. As a person who grew up in Japan, Maki spoke of what she has come to understand as an "active" attitude that is highly valued in the United States. For her, this attitude can be seen as a responsibility for communicating and pursuing one's own needs with a kind of assertiveness. In the United States, she sees people negotiating and talking with an active attitude. However, her experiences in Japan showed her that people there are expected to communicate and pursue their needs by pre-analyzing what other people may want first, in a way that, from the perspective of many Americans, may seem more indirect or "passive." Maki explained these cultural differences with this narrative:

Most Asian students feel ashamed to do such kinds of things. [We call] this kind of 'active attitude' Zuzushii. We have learned that these kinds of attitudes are rude and negative. [...] Many teachers here always say, "Come to talk to me if you don't understand or have any questions," and it is a basic thing to be expected to do in the US. However, it can be a very difficult thing to do for many students from Asian backgrounds because it is opposed to what they have learned throughout their lives as their social norms and values. I explain this to other teachers so often that I almost start to feel fed up with having to explain this (to them).... 
What Maki described as "Asian" is seen in different degrees among diverse Asian countries and may be felt more extremely for people from Japan. In the USA, many classroom teachers interpret their students' lack of seeking help as a lack of effort or laziness. However, this is not true in the context of schools in Japan. Knowing this, Maki proactively communicates with students and parents who have just arrived from Japan to help them better understand and prepare for these expectations:

It is not only okay, but also often even better to do something here (USA) that you feel could be Zuzushii (disturbing other people) in Japan. I tell them to abandon these hesitations. It is an important part of 'Life in America 101.'

Maki acknowledged that the meanings of "active" and "independent" are different in each society. Kei believes that how she modified her attitude and expectations informs her role as teacher, when she teaches students how to switch learning styles between two cultural contexts. Kei analyzed how she modified her attitude as a teacher when she taught a third grade student, Yumi, in Japanese and in English as a tutor at Yumi's house. Kei said it was not the language she was using but the cultural context in which she was teaching that made a difference:

Usually, Yumi and I don't care how we sit [Kei demonstrated how she might sit] when we studied English. But, when we practiced Japanese writing, I would say something like, 'You need to sit still and sit upright' or 'Put your left hand here, when you write...' But when we are studying English, I don't care. And Yumi is like that, too.

Kei said that it was not the languages she was using but the cultural context in which she was teaching that made a difference. Many of the transnational students, particularly from Japan, were sojourners and went/will go back to Japan depending on their parents' jobs, although some of them may choose to go to or come back to go to a college in the United States later.

Japanese-descent students who go back to Japan are called 帰国子女, Kikokushijo, (children who come back to the country) in Japanese. Although the situation for sojourners like them in Japan has been getting better; compared to how it used to be, the three teachers in this study acknowledge that sojourner students may be put in vulnerable situations when they return. Some of the cultural behaviors, ways of communication, or social values, which they acquired in the US, are so incompatible with those in Japan that they may be seen as different from mainstream Japanese people. The three of us know many stories about children who have had a difficult time after returning to Japan because they had adopted the new culture, social values, and communication styles from the US. They could no longer pass as "pure" Japanese in Japanese society. For instance, their pronunciation of English could be remarked on as "snobby" sometimes. And their more direct communication style may be perceived as "selfish" or Zuzushii. 
"We have stories to share!"

Maki explained:

The problem is when children take what they have learned in the USA as the truth. The younger they are, the more they just believe that what they have learned is the only truth, and they are going to get in trouble when they go back to Japan.

Political, social, cultural, and historical tension attached to the relationship between “English and US culture” and “Japanese and Japanese culture” make the 帰国子女 sojourners" situations even more complicated in Japanese society. This fact is one of the reasons why many parents who are planning to go back to Japan want Japanese Saturday School as the place to teach "authentic Japanese-ness" and "academic competency" to their children in as Japanese a manner as possible. The three teachers expressed their hope that students will be able to live with confidence in both cultures/countries.

\section{Nurturing Identity Development in the Context of Hybridity and Wholeness}

For immigrant children who occupy multiple cultural locations, identity development may be very complex (Vertovec, 2001). Transnational theorists argue that although many scholars have started to discard the notion of fixed identities and have incorporated the idea of multiple identities, there is still a dominating assumption that "individuals have a 'master,' overarching identity that is fundamentally rooted in a single place (Levitt, 2001, p. 202). This idea of a master, overarching identity or the need to be fundamentally one way or another is especially damaging for children who experience a sense of being torn between two worlds. Understanding identity as fixed and locked in dichotomous choices forces immigrant children to always living on the margin of each culture; as a result, many of them feel that they are unable to completely belong to either (Levitt, 2001; Suárez-Orozco \& Suárez-Orozco, 2001). The teachers in this study recognize this complexity and understand that identity is not fixed and singular but is multiple, hybrid, and fluid. It involves a creative process of construction and negotiation within and across multiple social locations and cultures (Bauman, 2006; Bhabha, 1994; Holland, Lachicotte, Skinner, \& Cain, 2001; Kawakami, 2006). Using their own experiences and understanding, they intentionally seek to scaffold their students' development of positive hybrid identities, self-acceptance, and agency.

For example, what Kei experienced as an adolescent when she was always seen as a Japanese person in local American schools which she went from $1^{\text {st }}$ grade to $12^{\text {th }}$ grade, and as an American when she was in the Japanese community, was the result of such an assumption of single rooted-ness. Meanwhile, Kei felt as though she did not belong anywhere:

I am like the moon because the moon is always there, but we only see a part of it. We cannot see the entire moon at any given time. This is similar to how other people see me.

Kei said that she was always able to talk about cross-cultural experiences with her family members, especially during dinnertime. It helped her to reflect on her own daily cross-cultural 
experiences and develop agency to move between two cultures and languages. Although she had great support and understanding from both of her parents, who are transnational, bicultural, and bilingual themselves, she still felt the lack of belonging, validation, and acceptance of who she is as a whole person from her classmates and teachers as a student in both US and Japanese cultural contexts.

In order to explain the sense of herself as a whole, Kei also used a metaphor of a cake. She was made by all different kinds of ingredients. Just as in a cake, each ingredient is important. Kei realizes that each ingredient completes her identities and all are important parts of who she is. Her own understandings and reflections on her crossing cultural, social, and racial experiences as a child informed her priorities for the education of immigrant children in her own classroom:

I want my students' life experiences to be validated and respected. I need to validate and respect my own experiences. The more honest I can be about who I am, the more honest I can be with my students.

The teachers in this study understood that many of their students face challenges when developing their sense of agency, or personal power, which grows with a sense of acceptance, validation, and respect in the community. Therefore, the students' identities were vulnerable and depended to a great degree on external factors since they are always trapped in between two different cultures. Therefore, these teachers repeatedly emphasized to their students the importance of developing a own sense of agency and confidence as cross/bicultural people.

Maki said, "I hope that my students will be able to live with confidence in both cultures and countries." She believes development of a positive identity is closely connected to the ability to culturally code-switch, which provides a foundation for competence and security for the students. Maki used the following metaphor of changing gears to explain cross-cultural codeswitching.

I tell my students to think of themselves as having many different gears. If they have only one kind of gear, they can live well in only one culture. I want my students to be able to live well in both cultural contexts. It is important to think of shifting gears. I tell them, 'Please have many different gears.' It is not like this gear is better and this gear is worse. It is the ability to consciously use many different gears depending on the situation.

This quote represents the students as drivers of their own cars; instead of just reacting, they can decide which gear they need/want to use while they are driving, and have the freedom to go wherever they choose.

Because of their vulnerability and the influence of external factors, it is important to create a safe space where the students can be themselves and talk about and explore their crosscultural experiences freely with adults who value such cross-cultural development of students. Kei wore a wide smile and shared this example: 
"We have stories to share!"

One Korean first-grade student was writing something, and I think that she knew she was not supposed to use a pen to write. But I guess she wanted to try, but [she] made a mistake while she was writing. She started to look very worried, wondering what she should do, but then the other first grader who is also from Korea said, 'Oh, that's okay, this is an American school.' And both laughed, and so did I.

While teaching sixth graders, multiple narrative data supported Gumiko's belief that her bilingual, cultural, social, and transnational life experiences and being a teacher/educator can uniquely provide a third space for her students, where they can talk about their own cross-, bicultural, bilingual, and hybrid experiences. In this third space, they can help each other to reflect and analyze their stories so that they can rewrite and re-interpret their stories and their own cross-cultural, lingual, and racial experiences together. Gumiko stated that she feels this is one of her priorities and she intentionally created such a space where students can accept each other's hybrid identities. She scaffolds students to move through these conversation collectively.

In one journal entry, Gumiko used Kei's cake metaphor and wrote, "I wanted to create a space in my classroom where all of my students can become 'cakes' with all the ingredients they have and they are wondering about. They don't need to choose or act just as Japanese or American but they can accept all the 'ingredients' they have.” As Gumiko told Maki:

One day, we talked about Japanese lunchboxes in my class at Hoshuko. Many of my students bring Japanese style bento boxes to their local public schools. They were talking about what "genchi-ko students" other students at local school in the US, commented about their lunch boxes and how they felt. One female student said with rather angry tone, 'I cannot understand why some Japanese students bring Japanese lunch boxes to local schools! They shouldn't. It looks very weird to American students. She added, 'We came here. We need to follow their ways, don't we? I don't want to think about and talk about my Japanese-ness. We have been trying so hard to become Americans every day.' She moved to US when she was four years old, I believe.

The student was deeply emotional in recounting her own experiences and how she developed her "strategies" to fit into the local school community. All other students were there with her while she expressed her anger toward unfairness and her struggles.

After expressing her strong emotion, she was the student who had so many things to tell: when she felt frustrated, or when she thought she was treated unfairly like given a question of how to divide a pizza with four people while she was much more capable for advanced math problems. She probably never had a space like this to talk and reflect her experiences with peers and adults who understood and listened to her cross-cultural, linguistic, racial experiences and voices. Another male student who was born in the US agreed with her, "That is right. My American friends said I was dirty and that I have no manners, because I was eating onigiri, a Japanese rice ball, with my hands." Then, I started to ask about sandwiches people eat with their hands. All students engaged deeply in the conversation. I have this kind of time with my students 
often, and I intentionally share my own experiences as an immigrant from Japan as a tool they may be able to use as flame of references and one of modes.

Gumiko made an effort by creating "a mutual aid society" (Gay, 2000). Gumiko recognized that many students were afraid of rejection from their American peers, who saw their differences as weird. Without having reflective space with more experienced peers or adults, the students may strengthen stereotypes, self-judgment, and even hatred of one culture or themselves. Therefore, she intentionally created a space to help the students process difficult emotions. For example, in reference to the above example, she helped the male student understand that eating a rice ball with his hands was not a dirty way to eat by making the connection that American students also eat sandwiches with their hands.

\section{Conclusion and Implications}

The three teachers in this study have lived and taught in both Japan and the United States and also have a great appreciation for both cultures. Many important people in their lives come from each of these countries. Throughout their lives, they have learned how to adjust to social norms in different cultural contexts and have developed a high level of bicultural competency. They have also developed fully integrated identities, and instead of being divided or torn between the two cultures, they experience a sense of wholeness. The experiences of these teachers, coupled with their understanding of and reflections on their own lives, have helped them develop a philosophy and an approach to teaching that is responsive to their students' strengths and needs. In this way, they demonstrate the pedagogy of shinayaka,しなやか. The literal meaning of shinayaka suggests a pliancy or flexibility, such as that of a bamboo tree. Bamboo trees have a very unique strength. If a bamboo tree is pulled to the right side, it bends to the right; if it is pulled to the left, it bends to the left. The bamboo's flexibility prevents it from breaking even when bent. When it is released, the bamboo tree straightens up again toward the sky.

The pedagogy of shinayaka as a theory, emerging from this study, can be used to theorize and reflect the life and learning and/or teaching experiences as cross-cultural culturallyresponsive teaching practices of these three teachers with their immigrant students of Asian descent, in particular mostly Japanese descent children. The image of the bamboo tree as it bends in the wind metaphorically mirrors the situations that immigrant children/youth often experience when having to negotiate between their home culture and the school/US dominant culture. Many Asian communities try to maintain their traditional values and way of life after they move to the United States and pass on their cultural heritage to their children (Pang, Kiang, \& Pak, 2004). At the same time, the generation of immigrant children/youth learn different cultural values from the new cultural context long-term and every day (Kawakami, 2006).

In dealing with these strong and often conflicting cultural values, the students are expected to bend to the right, and sometimes they are expected to bend to the left, without having many or any role adults models with similar experiences. In the process, some students may feel lost about which way they are facing and why. Some students may feel like they are losing the 
ability to return to an upright position toward the sky. Shinayaka represents the hopes of these teachers that their students will develop a flexible but strong cross-cultural consciousness - that they will experience a sense of wholeness and strength and can build a successful life in, between, and beyond both cultures. This process requires creativity, but will help them create unique hybrid and fluid identities with which they can benefit from both or any additional diversity (Kawakami, 2006).

The complexity of the cognitive, social, and academic development of ELL/immigrant students who are simultaneously living in two or more cultural and linguistic contexts while developing hybrid identity has not yet been researched enough from immigrant educators' point of view. Since there are more students from many more diverse backgrounds and more immigrant students, it is important to have a greater fund of knowledge from other immigrants, such as the three teachers in this study. More diverse studies of immigrant teachers will add their unique perspectives and significant contributions to reforming and strengthening teacher education programs. Thus, current and pre-service teachers can learn how to understand and serve more effectively immigrant children and to collaborate with their parents, caregivers, and communities. 


\section{References}

Au, K., \& Jordan, C. (1981). Teaching reading to Hawaiian children: Finding a culturally appropriate solution. Culture and the bilingual classroom: Studies in classroom ethnography, 139-152.

Bauman, Z. (2006). Liquid times: Living in an age of uncertainty. Cambridge, MA: Polity.

Bhabha, H. (1994). The location of culture. New York, NY: Routledge.

Bruner, J. (1986). Actual minds, possible worlds. Cambridge, MA: Harvard University Press.

Bruner, J. (1987). Life as narrative. Social Research, 54(1).

Bruner, J. (1996). The culture of education. Cambridge, MA: Harvard University Press.

Byrnes, D. A., Kiger, G., \& Manning, M. L. (1997). Teachers' attitudes about language diversity. Teaching and teacher education, 13(6), 637-644.

Chen, A. Y. P. (2017). Demographic imperativeness: Critical issues in preparing minority teacher candidates in teacher education. In Handbook of Research on Promoting CrossCultural Competence and Social Justice in Teacher Education (pp. 101-119). IGI Global.

Clandinin, D. J., Pushor, D., \& Orr, A. (2007). Navigating sites for narrative inquiry. Journal of Teacher Education, 58(1), 21-35.

Connelly, F. M., \& Clandinin, D. J. (1990). Stories of experience and narrative inquiry. Educational Research, 19(5), 2-14.

Connelly, F. M., \& Clandinin, D. J. (2006). Narrative inquiry. In J. L. Green, G. Camilli, \& P. Elmore (Eds.), Handbook of complementary methods in education research (3rd ed., pp. 477487). Mahwah, NJ: Lawrence Erlbaum.

Dillard, C. B. (2006). On the spiritual strivings: Transforming an African American woman's academic life. New York, NY: State University of New York Press.

Ellis, C. (2004). The ethnographic I: A methodological novel about autoethnography. Walnut Creek, CA: AltaMira Press.

English, B. (2009). Who is responsible for educating English language learners? Discursive construction of roles and responsibilities in an inquiry community. Language and Education, 23(6), 487-507.

Gay, G. (2000). Culturally responsive teaching: Theory, research, and practice. New York, NY: Teachers College Press.

Gay, G. (2002). Preparing for culturally responsive teaching. Journal of Teacher Education, 53(2), 106-116.

González, N., Moll, L. C., \& Amanti, C. (Eds.). (2005). Funds of knowledge: Theorizing practices in households, communities, and classroom. Mahwah, NJ: Lawrence Erlbaum.

Heron, J., \& Reason, P. (1997). A participatory inquiry paradigm. Qualitative Inquiry, 3(3), 274294.

Holland, D., Lachicotte, W. J., Skinner, D., \& Cain, C. (2001). Identity and agency in cultural worlds. Cambridge, MA: Harvard University Press. 
"We have stories to share!"

Howard, T. C. (2010). Why race and culture matters in schools: Closing the achievement gap in America's classrooms. New York, NY: Teachers College Press.

Howard, T. C. (2001). Telling their side of the story: African-American students' perceptions of culturally relevant teaching. The Urban Review, 33(2), 131-149.

Kanno, Y. (2003). Negotiating bilingual and bicultural identities: Japanese returnees betwixt two worlds. Mahwah, NJ: Lawrence Erlbaum.

Kawakami, I. (2006) Idou suru kodomotachi to Nihongo kyoiku: Nihongo wo bogo to shinai kodomo eno kotoba no kyoiku wo kangaeru [Children crossing borders and Japanese language teaching: Language education for children whose first language is not Japanese]. Tokyo: Akashi-shoten.

Ladson-Billings, G. (1994). The dreamkeepers: Successful teachers of African American children. San Francisco, CA: Jossey-Bass.

Ladson-Billings, G. (2014). Culturally relevant pedagogy 2.0: a.k.a. the remix. Harvard Educational Review, 84(1), 74-84.

Levitt, P. (2001). The transnational villagers. Los Angeles, CA: University of California Press.

Li, G, \& Sun, Z. (2019). Asian immigrant family school relationships and literacy learning: Patterns and explanations. In S. B. Sheldon, \& T. A. Turner-Vorbeck, The Wiley handbook of family, school, and community relationship in education (pp. 29-50). New York, NY: John Wiley \& Sons.

Li, G. (2012). Culturally contested pedagogy: Battles of literacy and schooling between mainstream teachers and Asian immigrant parents. New York: Suny Press.

Monobe, G. (2010). Narratives of Identity and Culturally Relevant Practices of Japanese Descent Teachers (Doctoral dissertation, The Ohio State University).

Monobe, G. \& Bedrosian, W. (2018, October). Unveiling complexity of an emergent bilingual/immigrant child's experiences using Bronfenbrenner's bioecological system theory. At the 26th International Reconceptualization of Early Childhood Education in Copenhagen, Denmark.

Mori, K. (1997). Polite lies: On being a woman caught between cultures. New York, NY: Henry Holt.

Ogbu, J. U. (1987). Variability in minority school performance: A problem in search of an explanation. Anthropology \& Education Quarterly, 18(4), 312-334.

Pang, V. O., Kiang, P., \& Pak, Y. (2004). Asian Pacific American students: Fighting overgeneralizations. In J. A. Banks (Ed.) \& C. A. McGee Banks (Assoc. Ed.), Handbook of research on multicultural education (2nd ed., pp. 542-563). San Francisco, CA: Jossey-Bass.

Patton, M. Q. (2002). Qualitative research and evaluation methods. Thousand Oaks, CA: Sage.

Reason, P. (1994). Three approaches to participative inquiry. In N. K. Denzin \& Y. S. Lincoln (Eds.), Handbook of qualitative research (pp. 324-339). Thousand Oaks, CA: Sage.

Reeves, J. R. (2006). Secondary teacher attitudes toward including English-language learners in mainstream classrooms. The Journal of Educational Research, 99(3), 131-143. 
Savin-Baden, M., \& Niekerk, L. V. (2007). Narrative inquiry: Theory and practice. Journal of Geography in Higher Education, 31(3), 459-472.

Suárez-Orozco, C., \& Suárez-Orozco, M. M. (2002). Children of immigration. Cambridge, MA: Harvard University Press.

Vertovec, S. (2001). Transnationalism and identity. Journal of Ethnic and Migration Studies, 27(4), 573-582.

Witherell, C., \& Noddings, N. (Eds.). (1991). Stories lives tell: Narrative and dialogue in education. New York, NY: Teachers College, Columbia University.

Wong, L. L. (2007). Transnationalism, active citizenship, and belonging in Canada. International Journal, 63(1), 79-99.

Yamada, H. (1997). Different games and different rules: Why Americans and Japanese misunderstand each other. Oxford, UK: Oxford University Press.

Yin, R. K. (2014). Case study research: Design and methods (5th ed.). Thousand Oaks, CA: Sage.

Yoshino, K. (2004). The Nihonjinron: Thinking elites' ideas of Japanese uniqueness. In M. Weiner (Ed.), Race, ethnicity and migration in modern Japan (Vol. 1, pp. 240-72). London, UK: Routledge.

Zhou, M. (1997a). Growing up American: The challenge confronting immigrant children and children of immigrants. Annual Review of Sociology, 23(1), 63-95.

Zhou, M. (1997b). Segmented assimilation: Issues, controversies, and recent research on the new second generation. International Migration Review, 975-1008. 